\title{
ATTITUDE OF DISTANCE LEARNERS TOWARDS MULTIMEDIA APPROACH TO INSTRUCTION
}

\author{
Hema Pant (panthema@yahoo.co.in) \\ Indira Gandhi National Open University, New Delhi
}

\begin{abstract}
Distance education is fast emerging as an alternative method for course delivery, thereby increases access to higher education at the national and international level. Distance education adopts a multimedia approach to instruction which differentiates it from the conventional mode of teaching-learning. The present study was undertaken to examine the attitude of distance learners towards multimedia approach to instruction. Participants were enrolled at Indira Gandhi National Open University, in its various programmes. An adapted attitude scale (Thurstone type) was administered to 1200 students, of which only 243 responded. Data analysis revealed a mean attitude score of 7.17 , indicating a favourable inclination of respondents to learn through the multimedia approach. Further research is warranted in this area to explore the attitude of learners in various other distance education settings. It would help distance educators to expand the outreach of education through distance mode, motivate learners and reduce attrition rates considerably.
\end{abstract}

Key words: attitude of distance learner, attitude scale, multimedia appraoch to instruction,

Distance education has emerged as a new system to meet the new demands of education. It aims to democratize education which is the need of the hour of the developing countries. Distance education is a non-formal system of education which combines in itself the new communication and education technologies in order to cater to a large section of the community. This alternative system of education which is cost effective and economically viable has a crucial role to play in meeting the challenges of the future.

An improvement over the correspondence system of education, distance education employs all possible means of communication. Learning material is supplemented through various other technologies like audio, video, computers etc. thereby enabling home-based study. Effort is made to build the teacher into the learning material itself and hence facilitate self learning. Technology is used to bridge the instructional gap (Willis, 1993) between the instructor and students who are removed from direct, immediate, physical contact (Hassenplug \& Harnish, 1998).

Distance education serves diverse learners, who are not able to participate in conventional classroom settings. Hence learners who opt for this mode of learning are highly motivated. In view of this it is important to examine the attitude of distance learners in order to be able to best serve them. 


\section{REVIEW OF LITERATURE}

Let us first examine the concept of attitude. Generally when we ask someone about his/her attitude toward something we are primarily concerned to know about their feelings, likes and dislikes towards the thing. Murphy (1931) has pointed out that a study of the early development of the individual child reveals that attitudes are first manifested in simple postural responses of acceptance or rejections. After reactions similar to those which accompany these early responses, eventually becomes characteristics of the individual's orientation to almost every situation he encounters.

Attitude according to Allport (1935) is the "Mental and neural state of readiness organized through experience, exerting a directive or dynamic influence upon the individual's response to all objects with which it is related." Put in simple words, what people feel or believe is their attitude. But it is difficult to measure people's attitudes. Researchers often have to depend on what people say or express as their beliefs and feelings (Best and Kahn, 2001).

In the present context, some studies have been conducted to study learner's attitudes towards distance education. Since distance education adopts a multimedia approach to impart instruction, it is important to explore the extent to which media use has proved useful for distance educators and its beneficiaries. Katz (2002), has opined that some abstract empirical studies have examined psychological aspects of the use of information and communication technology. These studies have indicated that certain psychological attitudes of students towards the use of ICT are of paramount importance when evaluating the effective use of distance learning approaches to instruction and learning. Distance learning at the tertiary level through the medium of ICT is seemingly affected by the same psychological attitudes that are known to be related to other successful ICT applications to learning and instruction. Katz's study examined the relationship between two distance learning ICT based configurations. The results indicate that the degree of efficiency in the use of distance learning approaches is differentially facilitated by the psychological attitudes of the distance learners.

Psychological factors which have a positive bearing on the students preferences for structured distance learning are, satisfaction with learning, level of control of the learning process and study motivation for distance learning. Whereas independence in learning is positively related to a student's preference for the use of internet.

Ashby (2002) reports that the most common technology employed for providing distance education is the Internet and the majority of distance education students are enrolled in subjects related to education, humanities and business. Further studies have revealed an increase in enrollment in distance education. In a study conducted by Srivastava (2002), $68 \%$ of community colleges and $54 \%$ of universities in Canada were offering distance education courses. 94\% of Canadian universities that had thus far not adopted distance education were planning to launch distance education programmes in the next five years. It has been reported in the same study that at the global level in 1998, the United States dominated the distance education scene, accounting for $76 \%$ of the courses being offered online. Canada accounted for $19 \%$, Australia $3 \%$, and other countries accounted for barely $2 \%$. However in India during the period 1975-2001, distance education increased from $2.6 \%$ to $20 \%$. The annual growth of distance education system is expected to be 30 to $40 \%$ as opposed to only a 5 to $10 \%$ growth for the formal education system. In another study by Tucker (2003), the portrait of distance learners in higher education was examined. Attitude of learners was one of the several characteristics studied. A questionnaire composed of 81 questions was used to determine 
overall satisfaction with distance education courses. Scores were based on a five point agreedisagree Likert type rating scale. The items assessed were:

i) Resistance to web based instruction - high scores reflected great resistance

ii) High procrastination tendencies

iii) High degree of satisfaction with the instructor

iv) High scores indicated high perceived quantity learned

v) High satisfaction with web based training and

vi) High self-efficacy.

An investigation into the students' reactions to the use of courseware as a learning tool in the classroom, involving young students, revealed that students as a whole were enthusiastic about using courseware as a tool for learning in the class, with a large number of students endorsing its motivational appeal and educational value. Despite the overall positive attitude however the data showed important difference between the reactions of male and female students to courseware male students being more confident that females, about using computers as a learning tool (Geoff Ring, 1991). A study by Joan Robson (1996) indicates that using teleconferencing in teaching Maths by distance education gives the students access to a flexible educational medium. Results confirm that this technology can support interaction between teacher and students similar to that in a conventional school. The investigation concludes that using teleconferencing in teaching Maths by distance education gives the student access to education that although different from that available in traditional classrooms, forms part of an effective teaching and learning environment. It also highlights the need to address pedagogical learning issues to maximize interaction within this environment. Another study assessed students' Attitudes Towards Web-based Learning Resources (Njagi, Smith and Isbell, 2003). The study assessed:

a) differences in attitude change, towards the Western Civilization class for students using webbased resources and those using traditional text books,

b) differences in attitude change, towards computer technology for students using web-based resources and those using traditional text books,

c) if age, gender, level in college, owning a personal computer, internet accessibility at home, hours spent on the internet per day etc. were predictors of attitude and

d) if level of computer literacy predicted students' attitude toward Western Civilization class and computer technology. Results indicated no significant difference in attitude change between the groups. However, there was a positive significant relationship between computer literacy and attitude towards computer technology. Among the demographic variables, gender and hire students spent on the Internet for class projects were found to predict positive attitude.

Nasser and Abouchedid (2000) investigated the attitudes and concerns towards distance education in Lebanon. The study explored the attitudes of school teachers and directors towards the worth and value of implementing a distance education programme in Lebanon. School directors were negative about the possibility of distance education meeting the training needs of school teachers. In addition, they reported costly training and the purchase of technologies for distance education as inconceivable. On the other hand, teachers held a more positive view of distance education. They expressed their willingness to put forth their efforts to familiarize themselves with new technologies and practices. 
Most of the studies have revealed distance learning to be advantageous over face-to-face instruction. However some studies point to the failure of technology in revolutionizing the process of learning and education. This has been highlighted in a study entitled "Technology in the classroom: The Teacher's New Role and Resistance to It", by Robert B. Hannafin and Wilhelminac Savenye. According to them bold predictions that video, film and instructional TV (ITV) could improve learning and revolutionize education have been unrealised. The disappointment following each of there innovations has left educators and researchers searching for an explanation.

Technology is thus influencing and exerting a major impact at every level of the educational system, particularly higher education. Owing to the increased usage of technology in the tertiary level of education, it is important to understand how instructional technology and the technologically rich environments are influencing student attitudes towards learning (Njagi, Smith, \& Isbell, 2003).

\section{THE STUDY}

\section{Methodology}

For the present investigation a descriptive survey approach was adopted. The study was focussed on the learners of Indira Gandhi National Open University.

A stratified random sampling technique was adopted to select the sample of students who were pursuing various programmes of IGNOU. For sample selection the programmes were categorised into four groups, namely, Certificate/Diploma Courses, Graduate degree, Post Graduate Diploma and Post Graduate degree courses. 1200 students were selected for the study. (Hema, 2003 )

\section{Tool Employed}

To obtain the attitude of students towards multimedia approach, an attitude scale (adapted attitude scale from a doctoral study by Menon M.B. 1984 ) was used. The method of equal appearing intervals by Thurstone was selected for measuring attitude of learners towards multimedia approach to instruction. The main reason for adopting this method is because it does not need the formulation of any norm for interpreting the attitude score of an individual. Twenty-two statements were selected to constitute the final form of the scale. The respondents were expected to go through each of the twenty-two statements carefully and put a tick mark if they agree to the statement or put a cross mark if they agree to the statement or put a cross mark if they disagree. The attitude scale was posted to the entire sample of students. Table 1 shows the attitude scale employed.

\section{ADMINISTRATION}

The adapted attitude scale was administered to the students to measure their attitude towards the use of multimedia in distance teaching and learning. However all respondents did not return the filled in attitude scale. The number of respondents who did return the attitude scale duly completed is 243 (20.25\%). 
Table-1. Attitude Scale: To measure the attitude of students to multimedia approach to instruction. (Menon M.B., 1984 )

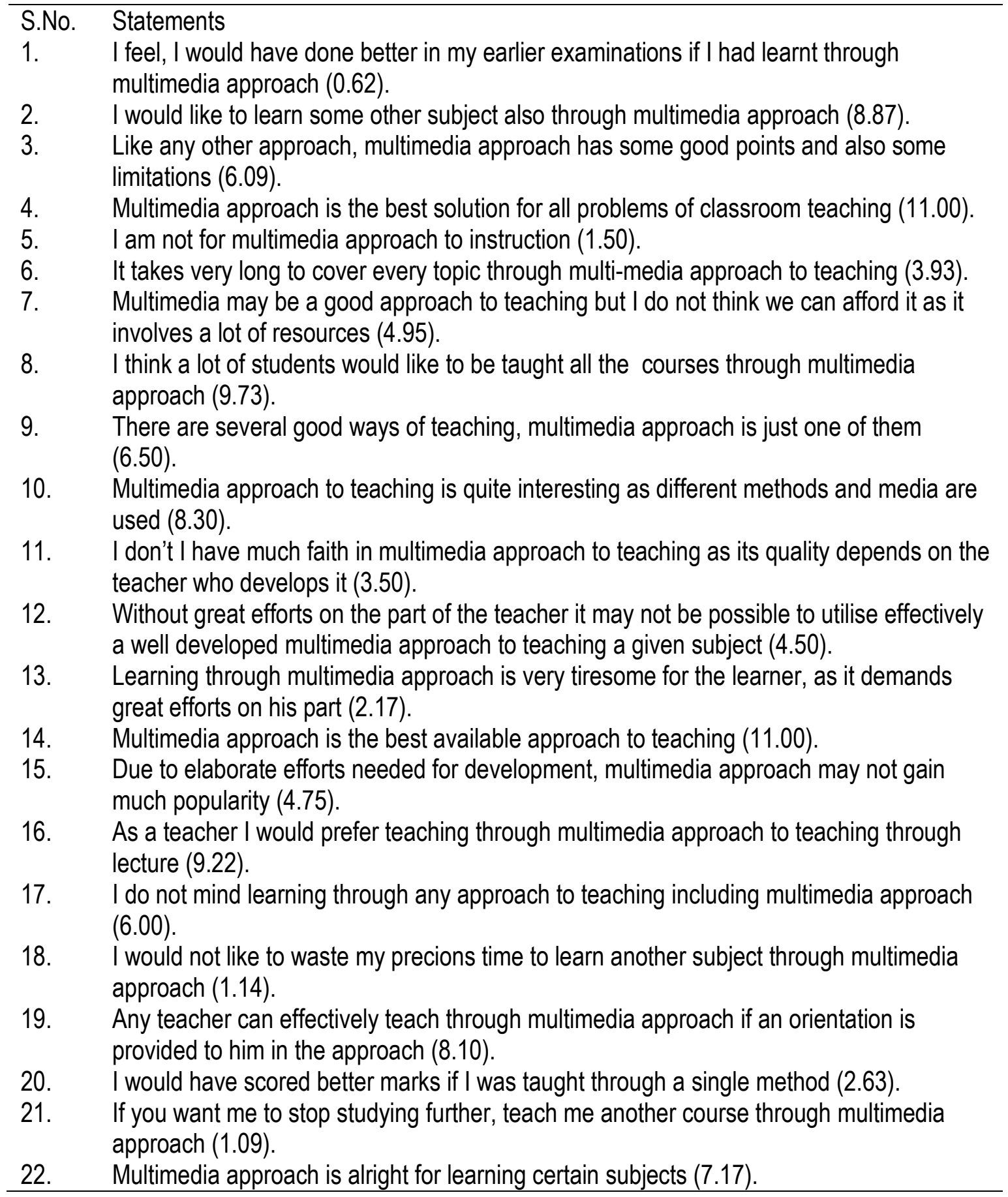

Note: Figures in parenthesis against each attitude statement indicate the scale value of that statement. 


\section{DATA ANALYSIS}

In Thurstone's method of equal appearing intervals, the attitude score of an individual is calculated by computing the median score of the scale values of all those statements of the scale which are endorsed by the individual. The attitude score of a tester is compared with the eleven point scale and attitude is interpreted accordingly. In the eleven point scale 6 denotes neutrality, above 6 upto 11 indicates various degrees of favourable attitude and below 6 upto 1 reflects various degrees of unfavourableness.

Accordingly the attitude scores of 243 respondents of IGNOU was calculated which results in e mean attitude score of 7.17 .

\section{INTERPRETATION}

The above analysis reveals a favourable attitude of the respondents towards multimedia approach to teaching as any value above 6 indicates various degrees of favourableness. Learners have revealed in inclination to learn through multimedia approach despite the inaccessibility of audio video material to them (Pant, 2003). Hence the university should make an earnest effort to strengthen multimedia as at instructional input to facilitate distance learning, making it more relevant, interesting and useful for the learners.

\section{DISCUSSION}

A predominant feature of distance learners is their hetrerogenous background . It directly influences and shapes their value systems which results in their dissimilar attitude ( Rathus and Nevid 1987). An individuals beliefs and values constitutes the basis of his/her attitude towards technology ( Paneer, Gebobotys 1992: Gardner, Duke \& Discenza, 1993). Technology has had a positive impact on the teaching-learning system as a whole which has brought about a more positive attitudinal change among learners. The intervention of communication and information technology and web based learning has facilitated formulation of a wide range of learning goals, objectives, projects, learning activities and excercises than the conventional class room system. Level of motivation and interest of the learners has thus increased substantially. Teaching has become more dynamic and both students and teachers are equally enthused and motivated. Teachers adopt a creative approach to teaching. According to Bill, " Online classrooms would yield desired results if ICT is combined with suitable pedagogy. The interactive feature of learning resources enables learners to become increasingly engaged in the construction of content and thus contribute to a more authentic learning situation. For instance students can access virtual libraries worldwide. Thus they have access to vast amounts of information and resources that are unattainable in a single instructional setting. [Bill, 1997 in ICT in Education for Asia-Pacific 2002, UNESCO Asia-Pacific Regional Bureau for Education, Bangkok, Thailand].

For the present study some limitations need to be considered in interpreting the results of the study. First, the students involved in the study were from only one open university of the country, namely Indira Gandhi National Open University, New Delhi, India. Second only 1\% of the students enrolled in the university were taken as the population. Third, students enrolled only in some programmes, falling under any of the four categories were selected randomly for the study. Keeping in mind these delimitations, generalizations from the study can be made. 
In conclusion, it can be said that the teaching and learning process has been greatly influenced by a variety of technological, instructional and pedagogical developments in the present times (Bonk \& King, 1998; Marina 2001). Distance education is one such technological revolution that combines the use of new communication technologies to reach out to larger segments of the population. A positive attitudinal change among both the learners and educators is required and the use of instructional technology catalyses this process by motivating them. Similar and more comprehensive studies should be undertaken to provide useful data on the successful utilization of present and future technologies into the various levels of education.

\section{REFERENCES}

Allport, W. (1935). Attitude in C. Murchenson (ed) Handbook of Social Psychology. Worcester Mess Clarke University Press.

Ashby, C.M. (2002). Distance Education: Growth in Distance Education programs and implications for federal education policy. United States General Accounting Office Report, GAO-02-1125T.

Best, John W. and Kahn, James V. (1989). Research in Education. New Delhi: Prentice Hall of India.

Bill, D.T. (1977). Beliefs and Values in ICT in Education for Asia-Pacific 2002. Bangkok, Thailand: UNESCO Asia-Pacific Regional Bureau for Education,.

Bonk, C.J. \& King, K.S. (1998). Electronic Collaborators: Learner Centred technologies for literacy, apprenticeship and discourse. Mahwah: Lawrence Erlbaum Associates..

Gardner, Donald, G., Dukes, Richard, L. \& Discenza Richard (1993). Computer use, Self Confidence and Attitudes, A Casual Analyses. Computers in Human Behaviour, 9(3), 427-440.

Hannafin, D.R. \& Savenye, C.W. (1993). Technology in the classroom: The teacher's new role and resistance to it. Educational Technology, 33(6).

Hassenplug, C.A. \& Harnish, D. (1998). The nature and importance of interaction in distance education credit classes at technical institutes. Community College Journal of Research \& Practice, 22(6), 591-606.

Katz, Y.J. (2002, March) Attitudes affecting College Students' preferences for distance learning. Journal of Computer Assisted Learning, 18(1), 2.

Marina, S.T. (2001, March). Facing the challenges, getting the right way with distance learning. Education at a Distance, 15 (30), 1-8.

Menon, M.B. (1984). Evolving a Multimedia Approach to teaching at post graduate level. Doctoral dissertation. India: University of Baroda.

Nasser, R. \& Abouchedid, K. (2000), Attitudes and concerns towards Distance Education: The case of Lebanon. Online Journal of Distance Learning Administration, 3(4).

Njagi, K., Smith, R. \& Isbell, C. (2003). Assessing Students' Attitudes Towards Web-based Learning Resources, World Wide Web.

Paneer, S.M., George, M. \& Gebotys, R.J. (1992). Understanding and predicting attitude towards computers. Computers in Human Behaviour, 8(2), 211-222.

Pant, H. (2003). A comparative study of the Instructional System Adopted by Indira Gandhi National Open University and other state Open Universities. Doctoral dissertation. Meerut, India: CCS University.

Rathus, Spencer Nevid \& Jefferey, S. (1987). Psychology and the challenges of Life (4th Ed). Forth Worth, TX: Holt, Reinhard and Winston, Inc. 
Ring, G. (1991). Students' reactions to courseware: Gender Difference. British Journal of Educational Technology,. 22(3).

Robson, J. (1996). The effectiveness of Teleconferencing in fostering interaction in distance education. Distance Education, 17(2).

Srivastava, M. (2002). A comparative study on current trends in distance education in Canada and India. Turkish Online Journal of Distance Education - TOJDE, ISSN 1302-6488, 3(4).

Tucker, S.Y. (2003). A portrait of Distance Learners in Higher Education. Turkish Online Journal of Distance Education - TOJDE June 2003, ISSN 1302-6488, 4(3).

Willis, B. (1993). Distance Education: A Practical Guide. Englewood Cliffs, NJ: Educational Technology Publications. 